Journal of Health Promotion and Behavior (2018), 3(2): 100-108

https://doi.org/10.26911/thejhpb.2018.03.02.03

\title{
Health Belief Model on the Choice of Medical Doctor among Mothers of Children with Diarrhea
}

\author{
Prita Yuliana Irnawati'), Harsono Salimo²), Yulia Lanti Retno Dewi3) \\ ${ }^{1)}$ Masters Program in Public Health, Universitas Sebelas Maret \\ 2)Departement of Pediatrics, Dr. Moewardi Hospital, Surakarta \\ 3)Faculty of Medicine, Universitas Sebelas Maret
}

\begin{abstract}
Background: Diseases among young children are the major causes of morbidity and mortality particularly in the developing countries. An estimated 13 million infants and children die annually in developing countries. In most developing countries, the health of the children is strongly dependant on maternal healthcare behavior. Evidence on health seeking behavior has been lacking in Central Java, Indonesia, particularly mother's choice to visit pediatrician rather than general practitioner for her ill child. The purpose of this study was to examine factors associated with the choice of medical doctor among mothers of children with diarrhea, using Health Belief Model.

Subjects and Method: A case control study was carried out at Sangkrah community health center, Surakarta, Central Java, in January 2017. A sample of 164 mothers was selected by fixed disease sampling. The dependent variable was mother's choice to visit doctor. The independent variables were perceived susceptibility, seriousness, threat, benefit, and barrier. The data were collected by questionnaire and analyzed by path analysis.

Results: The chance of mother decided to visit pediatrician rather than general practitioner was directly increased with strong perceived threat $(b=0.91 ; 95 \% \mathrm{CI}=0.24$ to $-1.57 ; \mathrm{p}=0.008)$, strong perceived benefit $(\mathrm{b}=0.85 ; 95 \% \mathrm{CI}=0.19$ to $1.50 ; \mathrm{p}=0.012)$, and decreased with strong perceived barrier $(b=-0.67 ; 95 \% \mathrm{CI}=-1.36$ to $0.01 ; \mathrm{p}=0.053)$. Mother's choice to visit pediatrician was indirectly affected by perceived susceptibility and perceived seriousness.

Conclusion: Mother's choice to visit pediatrician rather than general practitioner is directly increased with perceived threat, perceived benefit, and decreased with perceived barrier. Mother's choice to visit pediatrician is indirectly affected by perceived susceptibility and perceived seriousness.
\end{abstract}

Keywords: mother's choice, pediatrician, general practitioner, diarrhea, health believe model, children

\section{Correspondence:}

Prita Yuliana Irnawati. Masters Program in Public Health, Universitas Sebelas Maret, Jl. Ir. Sutami No. 36 A, Surakarta 57126, Central Java. Email: pritayuliana@gmail.com.

Mobile: +6287835140534 .

\section{BACKGROUND}

$\overline{\text { Diarrhea is a disease that can be prevented }}$ and treated easily, but it is still a global health problem, especially in developing countries including Indonesia. According to the Ministry of Health (2015), the incidence of diarrhea in children under five is $11.48 \%$. In Central Java, the incidence of diarrhea in infants is $21.57 \%$ and the incidence in Surakarta is $28.04 \%$ (Central Java
Provincial Health Office, 2015; Surakarta City Health Office, 2015).

The Indonesian government has designed a national diarrhea treatment pathway that is reflected through Integrated Management of Childhood Illness (IMCI). In diarrhea with mild classification, there are signs of anxious children; fussy or irritable; fast thirsty; stomach skin pinch is slow again, the treatment can be done at a 
primary level health facility that is directly handled by a general practitioner. Diarrhea is accompanied by complications, such as the condition of a toddler unconscious; sunken eyes; lazy to drink and pinch the stomach back very slowly, must be referred to secondary level health facilities handled by pediatricians (Hidayat, 2008; IDAI, 2014; Ministry of Health, 2015).

There are phenomena that occur in the community, namely the tendency of a mother who has a toddler with mild diarrhea who prefers to check her toddler to a pediatrician rather than to a primary health facility, in this case a general practitioner. The maternal knowledge about proper handling of diarrhea in children under five and giving ORS to children with diarrhea and the right time to consult with a doctor are very important to reduce the incidence of diarrhea in children under five.

In a preliminary study conducted in the work area of the Sangkrah Health Center, data obtained show that Sangkrah Health Center supervised Sangkrah, Kedunglumbu, and Semanggi villages. The incidence of diarrhea in children under five throughout 2015 in the Sangkrah Puskesmas working area is $37 \%$. From the results of interviews with several mothers who have children under five years, the underlying reason for a mother decides to check her toddler to a pediatrician including a mother who considers that diarrheal disease is a life-threatening disease, therefore it should be handled by a pediatrician . Diarrhea is also a disease that is considered serious by a mother, so that the treatment cannot be compared to other diseases that are considered lighter. The level of trust of a mother to a general practitioner in handling diarrhea in children under five is also still low.

The purpose of this study was to analyze factors associated with the choice of medical doctor among mothers of children with diarrhea, using Health Belief Model.

\section{SUBJECTS AND METHOD \\ 1. Study Design \\ This was an analytic observational study with a case control design. The study was carried out at Sangkrah community health center in Surakarta, in January 2017.}

\section{Population and Samples}

The target population in this study was mothers who had children under five. While the source population is mothers who have children under five in the work area of Sangkrah Health Center in Surakarta City. The sample size of this study was 164 subjects selected through fixed disease sampling with a ratio of 1: 1, namely the number of case subjects (mothers who examined their children to pediatricians) 82 and controls (mothers who examined their children to general practitioners) approximately 82 subjects.

\section{Study Variables}

The dependent variable was the choice of the type of doctor. The independent variables were the perceived susceptibility, perceived seriousness, perception threat, perceived benefit, and perceived barrier. The inclusion criteria consisted of mothers who had children under five had diarrhea.

\section{Operational Definition of Variables}

Perceived susceptibility was defined as maternal perception of the possibility of getting a disease. The greater perceived risk, the more likely it is to engage in behavior to reduce the risk.

Perceived seriousness was defined as maternal beliefs about the seriousness or severity of the disease. Perceived seriousness is often based on medical information or knowledge, it can also be based on someone's belief that he will have difficulties due to illness and will make or affect his life in general. 
Journal of Health Promotion and Behavior (2018), 3(2): 100-108

https://doi.org/10.26911/thejhpb.2018.03.02.03

Perceived of threat was defined as an individual's urge to take action to prevent or cure diseases caused by the perceptions of vulnerability and seriousness.

Perceived benefit was defined as a perceived benefit when adopting recommended behavior. Perception of benefits is a person's perception of the value or usefulness of a new behavior in reducing the risk of getting a good disease that benefits both physically and psychologically.

Perceived barrier were related to new behavior to be adopted. Someone must believe that the benefits of new behavior outweigh the consequences of continuing old behavior. This allows barrier to be overcome and new behaviors to be adopted.

Mother's choice of medical doctor was defined as maternal decision to visit pediatrician check her child suffering from diarrhea.

\section{Data Analysis}

Data analysis was performed using path analysis with the Stata 13 program to determine the effect of independent variables on

\begin{tabular}{|c|c|c|c|}
\hline No. & Characteristics & Frequency (n) & Percentage (\%) \\
\hline \multirow[t]{3}{*}{1.} & Maternal age & & \\
\hline & $<31$ years old & 80 & 48.8 \\
\hline & $\geq 31$ years old & 84 & 51.2 \\
\hline \multirow[t]{3}{*}{2.} & Education level & & \\
\hline & $<$ Senior high school & 96 & 58.5 \\
\hline & $\geq$ Senior high school & 68 & 41.5 \\
\hline \multirow[t]{3}{*}{3 . } & Maternal occupation & & \\
\hline & Working at home & 75 & $45 \cdot 7$ \\
\hline & Working outside of house & 89 & $54 \cdot 3$ \\
\hline \multirow[t]{3}{*}{4.} & Family income & & \\
\hline & $<\operatorname{Rp} 2,400,000$ & 87 & 53.0 \\
\hline & $\geq \operatorname{Rp} 2,400,000$ & 77 & 47.0 \\
\hline \multirow[t]{3}{*}{5 . } & Children's Age & & \\
\hline & Under three years old & 97 & 59.1 \\
\hline & Under five years old & 67 & 40.9 \\
\hline \multirow[t]{3}{*}{6.} & Number of children & & \\
\hline & $<2$ & 83 & 50.6 \\
\hline & $\geq 2$ & 81 & 49.4 \\
\hline
\end{tabular}

the dependent and determine the magnitude of the effect.

\section{Research Ethics}

The research ethical clearance was obtained from the Research Ethics Committee at Dr. Moewardi Hospital, Surakarta, Central Java, Indonesia. Research ethics included issues such as informed consent, anonymity, confidentiality, and ethical clearance.

\footnotetext{
RESULTS

1. Univariate Analysis

Univariate analysis in the study in table 1 is presented as follows. Table 1 shows that out of 164 study subjects, there were $51.2 \%$ of mothers aged $\geq 31$ years, $58.5 \%$ of mothers with education <senior high school, $54.3 \%$ of mothers who worked outside the home, and $53 \%$ of mothers had income $<\mathrm{Rp}$ $2,400,000$, and mothers who have children $<2$ children by $50.6 \%$.
} 
Table 2. The Description of Variable

\begin{tabular}{|c|c|c|c|}
\hline No & Characteristics & Frequency (n) & Percentage (\%) \\
\hline \multirow[t]{3}{*}{1.} & Perceived susceptibility & & \\
\hline & Weak & 61 & 37.2 \\
\hline & Strong & 103 & 62.8 \\
\hline \multirow[t]{3}{*}{2.} & Perceived seriousness & & \\
\hline & Weak & 46 & 28.0 \\
\hline & Strong & 118 & 72.0 \\
\hline \multirow[t]{3}{*}{3 . } & Perceived threat & & \\
\hline & Weak & 68 & 41.5 \\
\hline & Strong & 96 & 58.5 \\
\hline \multirow[t]{3}{*}{4.} & Perceived benefit & & \\
\hline & Weak & 73 & 44.5 \\
\hline & Strong & 91 & $55 \cdot 5$ \\
\hline \multirow[t]{3}{*}{5 . } & Perceived barrier & & \\
\hline & Weak & 60 & 36.6 \\
\hline & Strong & 104 & 63.4 \\
\hline
\end{tabular}
amount to $37.8 \%$, and those who have a high vulnerability perception amount to 62.8\%. Mothers who have low perceptions of seriousness amount to $28 \%$, and those who have a high perception of seriousness amount to $72 \%$.

Mothers with low threat perceptions amounted to $41.5 \%$, and those with high threat perceptions amounted to 58.5\%. Mothers who had a low perception of

\section{Bivariate Analysis}

Bivariate analysis was conducted to see the effect of independent variables (perceptions of vulnerability, perceptions of seriousness, perception of threat, perception of benefits, perception of obstacles with dependent variables (selection of types of doctors).

The analysis test used in bivariate analysis was chi square test with 95\% confidence degree $(\mathrm{p}<0.05)$. barriers amounted to $36.6 \%$, and those who

Table 3. Bivariate Analysis of the Effect of Independent Variables with the Selection of Doctor Types

\begin{tabular}{|c|c|c|c|c|c|c|c|c|}
\hline \multirow{3}{*}{ Variables } & \multicolumn{4}{|c|}{ The Selection of Doctor Types } & \multirow{3}{*}{ OR } & \multicolumn{2}{|c|}{ CI (95\%) } & \multirow{3}{*}{$\mathbf{P}$} \\
\hline & \multicolumn{2}{|c|}{ General doctor } & \multicolumn{2}{|c|}{ Pediatrician } & & \multirow{2}{*}{$\begin{array}{c}\text { Lower } \\
\text { limit }\end{array}$} & \multirow{2}{*}{$\begin{array}{c}\text { Upper } \\
\text { limit }\end{array}$} & \\
\hline & $\mathbf{N}$ & $\%$ & $\mathbf{n}$ & $\%$ & & & & \\
\hline \multicolumn{9}{|c|}{ Perceived susceptibility } \\
\hline Low & 38 & 62.3 & 23 & 37.7 & 2.22 & 1.16 & 4.23 & 0.015 \\
\hline High & 44 & 42.7 & 59 & $57 \cdot 3$ & & & & \\
\hline \multicolumn{9}{|c|}{ Perceived seriousness } \\
\hline Low & 38 & 62.3 & 23 & 37.7 & 2.01 & 1.01 & 4.21 & 0.037 \\
\hline High & 44 & 42.7 & 59 & $57 \cdot 3$ & & & & \\
\hline \multicolumn{9}{|l|}{ Perceived threat } \\
\hline Low & 43 & 63.2 & 25 & 36.8 & 2.51 & 1.33 & 4.77 & 0.004 \\
\hline High & 39 & 40.6 & 57 & 59.4 & & & & \\
\hline \multicolumn{9}{|l|}{ Perceived benefit } \\
\hline Low & 44 & 60.3 & 29 & 39.7 & 2.11 & 1.13 & 3.96 & 0.018 \\
\hline High & 38 & 41.8 & 53 & 58.2 & & & & \\
\hline \multicolumn{9}{|l|}{ Perceived barrier } \\
\hline Low & 23 & 38.3 & 37 & 61.7 & 0.47 & 0.24 & 0.91 & 0.023 \\
\hline High & 59 & 56.7 & 45 & $43 \cdot 3$ & & & & \\
\hline
\end{tabular}




\section{The Results of Path Analysis}

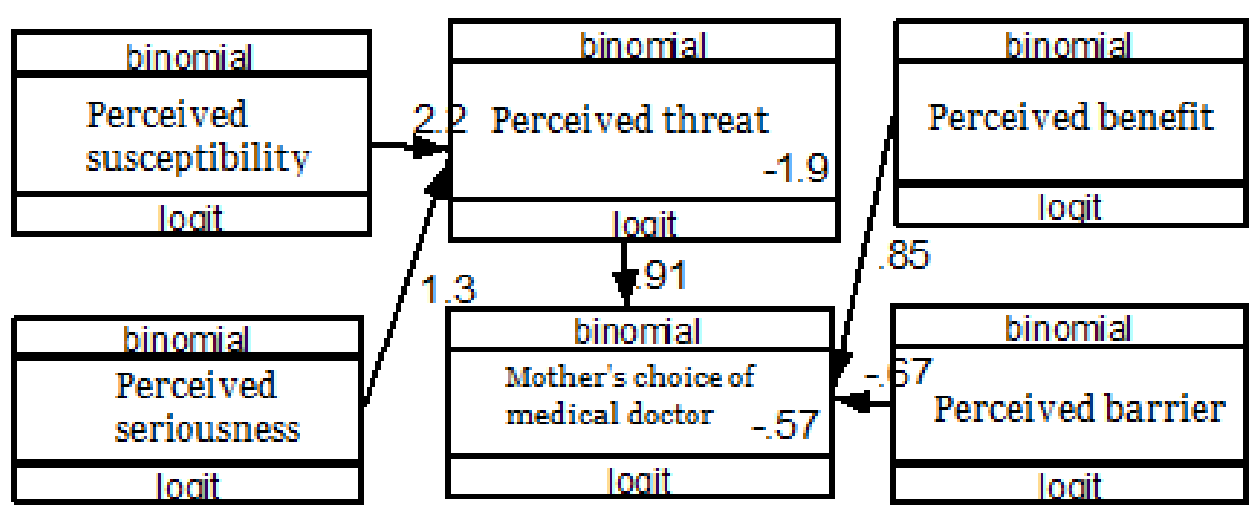

\section{Figure 1. Structural Model of Path Analysis with Estimation}

Table 4 showed that choice of medical doctor among mothers of children with diarrhea was affected by perceived susceptibility, perceived seriousness, perceived threat, perceived benefit, and perceived barrier.

Maternal choice to visit pediatrician was directly affected by perceived threat, perceived benefit, and perceived barrier.

Maternal choice to visit pediatrician was increased with strong perceived threat ( $\mathrm{b}=0.91 ; 95 \% \mathrm{CI}=0.24$ to $1.57 ; \mathrm{p}=0.008$ ),

Table 4. The Results of Path Analysis

\begin{tabular}{|c|c|c|c|c|c|c|}
\hline \multirow{2}{*}{ Dependent variable } & \multirow{2}{*}{\multicolumn{2}{|c|}{$\begin{array}{l}\text { Independent } \\
\text { variable }\end{array}$}} & \multirow[b]{2}{*}{ b } & \multicolumn{2}{|c|}{$95 \%$ CI } & \multirow[b]{2}{*}{$\mathbf{p}$} \\
\hline & & & & $\begin{array}{r}\text { Lower } \\
\text { Limit }\end{array}$ & $\begin{array}{l}\text { Upper } \\
\text { Limit }\end{array}$ & \\
\hline $\begin{array}{l}\text { Direct Effect } \\
\text { Maternal choice to visit }\end{array}$ & $\leftarrow$ & Strong perceived & 0.91 & 0.24 & 1.57 & 0.008 \\
\hline $\begin{array}{l}\text { Maternal choice to visit } \\
\text { pediatrician }\end{array}$ & $\leftarrow$ & $\begin{array}{l}\text { Strong perceived } \\
\text { benefit }\end{array}$ & 0.85 & 0.19 & 1.50 & 0.012 \\
\hline $\begin{array}{l}\text { Maternal choice to visit } \\
\text { pediatrician } \\
\text { Indirect Effect }\end{array}$ & $\leftarrow$ & $\begin{array}{l}\text { Strong perceived } \\
\text { barrier }\end{array}$ & -0.67 & -1.36 & 0.01 & 0.053 \\
\hline Perceived threat & $\leftarrow$ & $\begin{array}{l}\text { Strong perceived } \\
\text { susceptibility }\end{array}$ & 2.22 & 1.46 & 3.00 & $<0.001$ \\
\hline Perceived threat & $\leftarrow$ & $\begin{array}{l}\text { Strong perceived } \\
\text { seriousness }\end{array}$ & 1.28 & 0.43 & 2.12 & 0.003 \\
\hline $\begin{array}{l}\text { N Observation }=164 \\
\text { Log Likelihood }=-187.42\end{array}$ & & & & & & \\
\hline
\end{tabular}

and strong perceived benefit $(\mathrm{b}=0.85 ; 95 \%$ $\mathrm{CI}=0.19$ to $1.50 ; \mathrm{p}=0.012)$, but was decreased with strong perceived barrier $(\mathrm{b}=$ $-0.67 ; 95 \% \mathrm{CI}=-1.36$ to $0.01, \mathrm{p}=0.053$ ).

Maternal choice to visit pediatrician was indirectly affected by perceived susceptibility and perceived seriousness through perceived threat. Perceived threat was positively affected by strong perceived susceptibility $(\mathrm{b}=2.22 ; 95 \% \mathrm{CI}=1.46$ to 3.00; $\mathrm{p}<0.001)$ and perceived seriousness $(\mathrm{b}=1.28 ; 95 \% \mathrm{CI}=0.43$ to $2.12 ; \mathrm{p}=0.002)$. 


\section{DISCUSSIONS \\ 1. The effect of perceived susceptibi- lity on maternal choice to visit pediatrician}

The result of analysis showed that perceived susceptibility has an indirect effect on the choice of medical doctors through perceived threat. Mothers who have high perceived susceptibility would increase the choice of medical doctors (Pausir et al., 2014). The result of analysis was in line with a study done by Sukawana (2015), which stated that perceived susceptibility or personal risk was one of the strongest perceptions in encouraging people to adopt healthy behavior. The greater the perceived risk, the more likely it was to engage in behavior to reduce the risk. Perceived severity was related to individual beliefs about the seriousness or severity of the disease.

Perceived seriousness about diarrheal disease affected perceived threat, in addition, perceived susceptibility of diarrhea also affected the prevention of diarrhea by mothers. The role of parents in the prevention and treatment of diarrhea in children was very important. Factors that influenced were perceived susceptibility, seriousness, maternal age, level of education, maternal knowledge about healthy living, and the prevention of disease. Low perceived susceptibility was one of the causes of children who were late to be treated and late in getting help so that one of the impacts was dehydration during diarrhea. This was because the mothers did not have a low perceived seriousness related to the effects caused by diarrhea so that the mothers chose to provide treatment independently or check their children to a general practitioner (Gunawan, 2010).

\section{The effect of perceived serious- ness on maternal choice to visit pediatrician}

The result of analysis showed that there was an effect of maternal perception about the seriousness on the choice of medical doctors through perceived threat. The result of analysis was in line with a study done by Siswandwika et al. (2017), which showed that low perceived seriousness was o.34 times less likely to have high perceived threat, this was because an individual who felt that diarrheal disease was not a serious disease would have a greater likelihood of taking the treatment by checking her/his child to a general practitioner.

Perceived seriousness of the individual's perceived illness refer to the feeling of the severity of the illness and the perceived threat to the clinical impact and possible consequences (death, disability and illness), thus giving the appropriate treatment for the child to a pediatrician (Sigler et al., 2014).

Perceived seriousness felt by the mothers were influenced by many factors, including maternal knowledge about diarrhea, education, national health insurance participation, adequate health facilities, distance to health facilities, and maternal employment (Shazma et al., 2016). Based on the results of the study, it was known that most of the research subjects have a low level of education, it could affect low maternal perceived seriousness because the maternal knowledge about diarrhea treatment was poor. Strong perceived seriousness would affect the proper prevention and treatment of diarrhea, in addition, healthy behavior was done as an effort to prevent the occurrence of diarrhea (Vega, 2013). 
Journal of Health Promotion and Behavior (2018), 3(2): 100-108

https://doi.org/10.26911/thejhpb.2018.03.02.03

\section{The effect of perceived threat on maternal choice to visit pediatrician}

The result of analysis showed that perceived threat increased the choice of medical doctors. The result of this study showed that research subjects with high perceived threat checked their children to a pediatrician. In Health Belief Model (HBM) theory, individuals would perform health behaviors based on perceived threat of health problems.

This study was in line with a study done by Adamo and Brett (2013), which stated that the feeling of being threatened or worried arised from the perception that individuals were susceptible to health problems and these problems can lead to serious consequences, thus the choice of pediatricians was a form of maternal attitude because they felt that diarrheal disease in their children was a disease that must be treated immediately.

Al-mazrou et al. (2002) explained that the choice of pediatricians for diarrhea treatment was affected by a high perceived threat to encourage the belief or attitude of mothers who believe that diarrhea was a disease that must be treated immediately so that pediatrician was the maternal choice for the treatment of their children.

Good knowledge about the signs of diarrheal disease was highly important to be known by the mother as an initial reference in taking appropriate treatment to avoid complications or child mortality due to diarrhea (Adisasmito, 2007).

Better knowledge of diarrheal diseases affected maternal perceived threat to diarrheal diseases, therefore, mothers with high perceived threat chose treatment at pediatricians as an effort to treat diarrhea.

\section{The effect of perceived benefit on maternal choice to visit pediatrician}

The result of analysis showed that perceived benefit increased the choice of medical doctors. The result of this study was supported by a study of Lee et al. (2015), which showed that mother with high perceived benefit related to diarrhea treatment especially the choice of doctors affected the treatment for children with diarrhea.

General practitioners did not limit their practice to certain diseases or certain treatment methods. While specialist doctor according to WHO was doctor who diagnose, cure, and prevent diseases, injuries, other physical and mental disorders, and maintain general health in humans through the implementation and procedures of modern medicine (Budhathoki et al., 2016). Specialist doctors specialized in certain categories of diseases, types of patients or treatment method, could carry out education and research in the area of specialization they chose. Knowledge regarding the authority of the doctor need to be known by the mothers so that they were able to choose a doctor who was suitable for children with diarrhea. In addition, high knowledge also affected the perceived benefit of mothers for the diarrhea treatment (Gunawan, 2014).

High perceivd benefit of treatment affected the choice of specialist doctors for the diarrhea treatment and also encouraged the mothers to take preventive actions for diarrhea complications or prevention to stop the diarrhea. Therefore, perceived benefit related to appropriate treatment for diarrhea encouraged the mothers to provide the best treatments, one of them was by checking the children at a pediatrician. 
Journal of Health Promotion and Behavior

https://doi.org/10.26911/thejhpb.2018.03.02.03

\section{The perceived barrier on maternal choice to visit pediatrician}

The result of this study showed that perceived barrier decreased the choice of medical doctors. The result of this study was supported by a study of Cuevas (2015), which stated that mothers with low perceived barrier were more likely to do diarrhea treatment at general practitioner because they felt that the treatment of diarrhea in general practitioners were more accessible, it was influenced by many other factors. Equselassie (2012) described that factors that affected perceived barriers include access to services, income, previous experience, and knowledge.

Mohebi et al. (2013), explained that maternal knowledge about diarrhea affected the treatment for the children. Perceived susceptibility and seriousness of the disease affected the treatment given by the mothers, in addition, other factors that affected were the educational status, previous experience in managing the disease, perceived barriers and benefits to the treatment. Perceived barries could arise due to many influential factors, lack of access to information related to appropriate treatment was one of the factors related to the maternal perceived barriers in determining the type of doctor to the treatment of their children.

Amare et al. (2012) explained that perceived barrier affected the choice of treatment for toddlers with diarrhea. Another study also found that the treatment of diarrhea in toddlers was strongly influenced by maternal attitude in perceiving the diarrhea, and maternal perception of diarrheal disease which supported by the condition of a baby or child who have diarrhea (Ambreen et al., 2016).

Child condition who were considered stable and able to move as usual made mothers have a perception that diarrheal disease was not a serious threat to their children, on the contrary, high perceived threat was able to affect the mothers to provide treatment by checking their children to a pediatrician (Ibrahim and Shankar, 2012).

\section{REFERENCES}

Adamo KB, Brett KE (2013). Parental Perceptions and Childhood Dietary Quality. Maternal and Child Health Journal. doi: 10.1007/s10995-013-1326-6.

Adisasmito W (2007). Faktor Risiko Diare pada Bayi dan Balita di Indonesia: Systematic Review Penelitian Akademik Bidang Kesehatan Masyarakat. Makara, Kesehatan. 11(1): 1-10.

Al-mazrou YY, Khan MU, Aziz KMS (2002). Factors Associated with Diarrhoea Prevalence in Saudi Arabia. Journal of Family and Community Medicine. 2(1): 27-34.

Amare B, Moges B, Fantahun B, Tafess K, Woldeyohannes D, Yismaw G, Ayane T, Yabutani T, Mulu A, Ota F, Kassu A (2012). Micronutrient Levels and Nutritional Status of School Children Living in Northwest Ethiopia. Nutrition Journal, 11(1): 1. doi: 10.1186/1475-2891-11-108.

Ambreen A, Marie A (2016). Knowledge and Practices of Mother Regarding Diet during Diarrhea and Respiratory Tract Infections among Children under Five years Attending Family Medicine Clinics of a Teaching Hospital, Karachi. Journal of Pioneering Medical Sciences, 6(2): 45.

Budhathoki SS, Bhattachan M, Yadav AK, Upadhyaya P, Pokharel PK (2016). Eco-social and behavioural determinants of diarrhoe in under-five children of Nepal: a framework analysis of existing literature. BioMed Central Tropical Medicine and Health. 44(7): 
Journal of Health Promotion and Behavior (2018), 3(2): 100-108

https://doi.org/10.26911/thejhpb.2018.03.02.03

1-7

Enquselassie F (2012). A Case Control Study on Determinants of Diarrhea Morbidity among Under-Five Children in Wolaita Soddo Town, Southern Ethiopia. Ethiopian Journal of Health Development, 26(2): 78-85.

Mohebi S, Matlabi M, Shahsiah. (2013). The Effectiveness of Nutrition Education Program Based on Health Belief Model Compared with Traditional training. Journal of Education and Health Promotion. 2(1): 15. doi: 10.4103/2277-9531.112684.

Pausi R, Suriah, Rachman WA (2014). Perilaku Ibu Balita terhadap Pencarian Pengobatan Penyakit Diare di Wilayah Kerja Puskesmas Cendana Putih Kecamatan Mappedeceng Kabupaten Luwu Utara. Fakultas Kesehatan Masyarakat Universitas Hasanuddni.

Sigler R, Mahmoudi L, Graham JP (2015). Analysis of Behavioral Change Techniques in Community-led Total Sanitation Programs. Health Promotion
International, 30(1): 16-28. doi: 10.1093/heapro/dauo73.

Shazma, Nazneen S, Ul-Haq N, Shah A, Jahan S (2016). Frequency of Diarrhea and Its Risk Factor among Children under Five Years in Three Teaching Hospital of Peshawar, Pakistan. International Journal of Innovative Research and Development, 5(12): 8-11.

Siswandwika HD, Murti B, Dharmawan R (2017). Biopshychosocial and Economic Determinants of Personal Hygiene in the Prevention of Diarrheal Diseases in Sragen District, Central Java. Journal of Health Promotion and Behavior. 2(1): 1-14.

Vega NS (2013). Knowledge, Attitudes and Traditions Regarding Water Consumption and Sanitary Practices of the Ngabe-Bugle Indigenous Women in the Chiriqui Province in Panama. ProQuest Dissertations and Theses. p. 115 . 